\title{
Comparison of maternal and perinatal outcome in pregnancy with altered thyroid profile and euthyroid patients: a prospective, observational and case control study in a tertiary care centre
}

\author{
Vandna Singh*, Neeta Natu, Artika Sudhir Gupta
}

Department of Obstetrics and Gynecology, SAIMS and PGI, Indore, Madhya Pradesh, India

Received: 28 January 2019

Accepted: 05 March 2019

*Correspondence:

Dr. Vandna Singh,

E-mail: vandana.singh297@gmail.com

Copyright: () the author(s), publisher and licensee Medip Academy. This is an open-access article distributed under the terms of the Creative Commons Attribution Non-Commercial License, which permits unrestricted non-commercial use, distribution, and reproduction in any medium, provided the original work is properly cited.

\begin{abstract}
Background: Thyroid disease is one of the commonest endocrine disorder affecting women of reproductive age, and when untreated during pregnancy is associated with an increased risk of complications. The objective of this review was to increase awareness and to provide a review on adverse effect of thyroid dysfunction on maternal and perinatal outcome.

Methods: This prospective, observational hospital-based case-control study carried on women coming for antenatal check-up in a Tertiary Care Hospital in INDORE from May 2018-December 2018. 50 known booked antenatal (case) patient with established thyroid disorder, more than 32 week of gestation, and 50-matched euthyroid patients (control) were taken.

Results: Women suffering from overt and subclinical hypothyroidism and hyperthyroidism are nulliparous in $72 \%$ cases as compared to $32 \%$ in euthyroid patient. Increased maternal age was associated with higher incidence of thyroid dysfunction. Normal vaginal delivery by spontaneous labour seen in $56 \%$ of euthyroid, while it is reduced with thyroid dysfunction. $38 \%$ of altered thyroid profile patient undergo induction of labour and $24 \%$ cases undergo caesarean section as compared to control (17\%). Adverse fetal outcome like intrauterine growth retardation, preterm birth and ICU admission seen increased with thyroid dysfunction as compared to euthyroid patients.

Conclusions: Thyroid dysfunction in pregnancy, although has a low incidence, but is associated with adverse maternal and fetal implications. Thus, thyroid screening should be done in antenatal period to improve fetomaternal outcome.
\end{abstract}

Keywords: Antenatal outcome, Hyperthyroidism, Hypothyroidism, Perinatal outcome, Thyroid dysfunction

\section{INTRODUCTION}

Thyroid hormones have profound variation during the life span and are associated with severe adverse health impacts. Pregnancy, as an important reproductive event, has a profound but reversible effect on the thyroid gland and its function. ${ }^{1-3}$ Pregnancy is actually a state of excessive thyroid stimulation leading to an increase in thyroid size by $10 \%$ in iodide sufficient areas and 20 -
$40 \%$ in iodide deficient regions. Furthermore following the physiological and hormonal changes caused by pregnancy and human chorionic gonadotropin (HCG) the production of thyroxin (T4) and tri-iodothyronine (T3) increase up to $50 \%$ leading to $50 \%$ increase in a woman's daily iodide need, while Thyroid-stimulating hormone (TSH) levels are decreased, especially in first trimester. ${ }^{1-3}$ Compared to hyperthyroidism, hypothyroidism is very common during pregnancy; $2-3 \%$ of pregnant women 
suffer from hypothyroidism $(0.3-0.5 \%$ overt hypothyroidism and 2-2.5\% subclinical hypothyroidism). ${ }^{4,5}$ Pregnancy can imitate some of the signs that are observed in hypothyroidism, including fatigue, anxiety, constipation, muscle cramps, and weight gain; as a result, the clinical diagnosis of hypothyroidism during pregnancy may be difficult. ${ }^{6,7}$

Moreover, most signs of hypothyroidism can be hidden by a woman's status following the increase in metabolism in pregnancy.

Furthermore, the thyroid hormonal profile in normal pregnancy can be mis-interpreted as hypothyroidism and as a result the interpretation of thyroid function tests needs trimester-specific reference intervals for a specific population. ${ }^{8,9,10}$

Inadequately treated or subclinical hypothyroidism increases the risk for miscarriage and fetal death, anemia, postpartum haemorrhage, placental abruption, cardiac dysfunction, preeclampsia, gestational diabetes, and preterm births whereas adequately treated hypothyroidism only increases the risk for cesarean sections. $^{11-13}$

Overt hyperthyroidism during pregnancy was not prevalent and was reported in 2 out of 1000 pregnancies $(0.2 \%)$, while subclinical hyperthyroidism was occurred in $1.7 \%$ of pregnancies. ${ }^{14,15}$ The most prevalent reason for hyperthyroidism during pregnancy was the transient hyperthyroidism resulting from hyperemesis gravidarum (THHG) due to the thyroid stimulation of beta-HCG. ${ }^{16}$

The natural physiological changes during pregnancy can mimic some of the signs observed in hyperthyroidism, including increased in basal metabolism, heart rate, fatigue, anxiety, palpitations, heat intolerance, warm and wet skin, hand tremors and systolic murmur. ${ }^{17,18,19}$ Poor control of hyperthyroidism during pregnancy is also associated with increased risk of miscarriage and stillbirth, hypertension in pregnancy, preterm births, and maternal heart failure..$^{20,21}$

Race/ethnicity may be important in modifying the potential risks thyroid diseases pose during pregnancy because the risk of hyperthyroidism and hypothyroidism in the population and predisposition to adverse outcomes in pregnancy varies by race/ethnicity.

\section{METHODS}

The present observational, prospective hospital-based case-control study. was conducted in the Department of Obstetrics and Gynaecology, SAIMS and PGI, Indore during the time May 2018 to December 2018.

50 knowns booked pregnant patients (case) with established thyroid disorder with more than 32 week of gestation and 50 matched euthyroid patient (control) who attended the antenatal clinic regularly during the period were recruited for study. The study was started after obtaining ethical clearance from institute ethical review board.

\section{Cases}

50 known thyroid disease patients (subsequent cases)

\section{Inclusion criteria}

- Known pregnant patients with thyroid disorders and those having symptoms and signs suggestive of hypothyroidism and hyperthyroidism.

Booked patients following up regularly for antenatal check up and who delivered at SAIMS and PGI, Indore

\section{Exclusion criteria}

- Other medical disorders like pregnancy induced hypertension, diabetes.

\section{Controls}

50 euthyroid pregnant patients. Every patient's thyroid level should be checked attending the antenatal clinic in the study duration (50 patient) and fulfilling the inclusion and exclusion criteria was taken as a matched control.

\section{Inclusion criteria}

- No other medical disorder

- No obstetric risk factors

- Patients with a history of spontaneous abortion but with no identifiable or known cause

\section{Exclusion criteria}

H/o. LSCS for non-obstetric indication

\section{Study procedure}

Based on the inclusion and exclusion criteria, 50 patients in each group were selected from the Department of Obstetrics and Gynaecology, SAIMS and PGI, Indore.

The nature and purpose of the study was explained to the patients.

History, examination findings on antenatal visit, on admission and during the stay in hospital and investigations in chronological order were taken on the predesigned Performa by the Chief Investigator herself.

In the patients of thyroid disorder, besides the routine antenatal profile and ultra-sonography, thyroid function tests served as the guiding investigations in the 
management of pregnancy. The T3, T4 and TSH levels were done on their first visit. According to the values, thyroxin dose was revised for hypothyroid patients and for hyperthyroid patient Later on, in the pregnancy, T3, T4 and TSH levels were done every 6-8 weeks or whenever required with respect to the signs and symptoms of the patient, fetal growth parameters and any dose revision.

In the euthyroid patients, besides the routine antenatal profile and ultra-sonography examination, T3, T4 and TSH level were done anytime between 16-20 weeks of gestation.

Whenever the patient was admitted to the hospital, either in labour or for any complication, she was managed appropriately.

The basic guidelines for management included maintaining euthyroid state of tile mother (in cases) and assuring a good maternal and fetal outcome.

After delivery the cord blood samples of neonate was sent for T3, T4, TSH level estimation and according to the initial values, babies were given thyroxine replacement therapy and followed-up later.

\section{Statistical analysis}

The statistical difference between the foetal outcome in the cases and controls were compared by Chi-square test.

\section{RESULTS}

The patients were divided into the following groups according to thyroid function test results:

Group 1: Euthyroid, defined as normal TSH (0.2-3.0 $\mu \mathrm{IU} / 1)$.

Group 2: Subclinical hypothyroid, defined as high TSH $(>3.0 \mu \mathrm{IU} / \mathrm{l})$ in the presence of normal levels of Free T4 $(0.8-2.0 \mathrm{ng} / \mathrm{dl})$.

Group 3: Overt hypothyroid, defined as high TSH (>3.0 $\mu \mathrm{IU} / \mathrm{l})$ with low Free T4 $(<0.8 \mathrm{ng} / \mathrm{dl})$.

Group 4: Subclinical hyperthyroid, defined as low serum TSH $(<0.2 \mu \mathrm{IU} / 1)$ concentration with normal Free T4 $(0.8-2.0 \mathrm{ng} / \mathrm{dl})$.

Group 5: Overt hyperthyroid, defined as with high Free T4 (>2.0 ng/dl) with decreased TSH $(<0.2 \mu \mathrm{IU} / \mathrm{l})$.

Thyroid dysfunction is associated with adverse fetal outcomes in pregnancy. The data on hypothyroidism were more conclusive than in hyperthyroidism as the sample size in the hyperthyroidism group was small and the disease is comparatively infrequent. Women suffering from overt and subclinical hypothyroidism and hyperthyroidism are nulliparous in $72 \%$ cases as compared to $32 \%$ in euthyroid patient (Table 1 ).

Table 1: Relation of parity and thyroid disorder.

\begin{tabular}{|c|c|c|c|c|c|}
\hline Parity & $\begin{array}{l}\text { Euthyroid } \\
\mathbf{n}=\mathbf{5 0}, \mathbf{N}(\%)\end{array}$ & $\begin{array}{l}\text { Sub clinical } \\
\text { hypothyroid } \\
\text { n=35, N }(\%)\end{array}$ & $\begin{array}{l}\text { Overt } \\
\text { hypothyroid } \\
\mathrm{n}=12, \mathrm{~N}(\%)\end{array}$ & $\begin{array}{l}\text { Subclinical } \\
\text { hyperthyroid } \\
n=2, N(\%)\end{array}$ & $\begin{array}{l}\text { Overt } \\
\text { hyperthyroid } \\
\mathbf{n = 1 , N}(\%)\end{array}$ \\
\hline Nulliparous & $16(32)$ & $25(71.4)$ & $9(75)$ & $01(50)$ & $01(100)$ \\
\hline Primiparous & $15(30)$ & $8(22.85)$ & $3(25)$ & $01(50)$ & 00 \\
\hline Multiparous & $19(38)$ & $02(5.71)$ & 00 & 00 & 00 \\
\hline
\end{tabular}

Table 2: Relation of age with thyroid disorder.

\begin{tabular}{|c|c|c|c|c|c|}
\hline Age (year) & $\begin{array}{l}\text { Euthyroid } \\
n=50, N(\%)\end{array}$ & $\begin{array}{l}\text { Subclinical } \\
\text { hypothyroid } \\
\text { n=35, N }(\%)\end{array}$ & $\begin{array}{l}\text { Overt } \\
\text { hypothyroid } \\
\mathrm{n}=12, \mathrm{~N}(\%)\end{array}$ & $\begin{array}{l}\text { Subclinical } \\
\text { hyperthyroid } \\
\mathbf{n = 2 , N}(\%)\end{array}$ & $\begin{array}{l}\text { Overt } \\
\text { hyperthyroid } \\
\mathbf{n = 1 , N}(\%)\end{array}$ \\
\hline Less than 20 & $10(20)$ & $02(5.71)$ & 00 & 00 & 00 \\
\hline $21-25$ & $17(34)$ & $09(25.71)$ & $01(8.33)$ & $01(50)$ & 00 \\
\hline $26-30$ & $15(30)$ & $13(37.1)$ & $7(58.3)$ & $01(50)$ & $01(100)$ \\
\hline More than 30 & $8(16)$ & $11(31.4)$ & $4(33.4)$ & 00 & 00 \\
\hline
\end{tabular}

In present study noted that increased maternal age was associated with higher incidence of thyroid dysfunction. Median age of our cases 28.5 year as compared to Nidhi et al 22 which was 26.7 year. (Table 2). $\mathrm{P}=0.54$ (the difference between the two groups is not statistically significant) was found in Table 3. Also, it shows that normal vaginal delivery by spontaneous labour seen in $56 \%$ of euthyroid, $17.1 \%$ of subclinical hypothyroid, $16.7 \%$ of overt hypothyroid and $50 \%$ of subclinical hyperthyroid patient. $38 \%$ of altered thyroid profile 
patient undergo induction of labour and $24 \%$ cases undergo caesarean section as compared to control (17\%) (Table 3). $\mathrm{P}=0.04$ (the difference between the two groups is statistically significant) found in table 4 . It also shows adverse fetal outcome preterm birth in $33.4 \%$ of overt hypothyroid cases, $17.14 \%$ of subclinical hypothyroid cases as compared to $16 \%$ of euthyroid patient. In $58.33 \%$ of overt hypothyroid patient, $40 \%$ of subclinical hypothyroid patient have low birth weight baby as compared to $18 \%$ of euthyroid patient. Intrauterine growth retardation found in $41.7 \%$ of overt hypothyroid patient baby which was statistically significant as compared to $4 \%$ of euthyroid patients' baby (Table 4 ). $\mathrm{P}=0.064$ (the difference between the two groups is statistically significant) was found in table 5. It also shows $58.3 \%$ of overt hypothyroidism, $34.28 \%$ subclinical hypothyroid patient's baby undergo ICU admission as compared to $10 \%$ euthyroid patient. ICU admission not found in hyperthyroid patient's baby (Table 5).

Table 3: Mode of delivery.

\begin{tabular}{|c|c|c|c|c|c|}
\hline Foetal outcome & $\begin{array}{l}\text { Group } 1 \\
\text { (euthyroid) } \\
\mathbf{n}=\mathbf{5 0}, \mathbf{N}(\%)\end{array}$ & $\begin{array}{l}\text { Group } 2 \\
\text { (subclinical } \\
\text { hypothyroid) } \\
\mathbf{n = 3 5}, \mathbf{N}(\%)\end{array}$ & $\begin{array}{l}\text { Group } 3 \\
\text { (overt } \\
\text { hypothyroid) } \\
\text { n=12, N (\%) }\end{array}$ & $\begin{array}{l}\text { Group } 4 \\
\text { (subclinical } \\
\text { hyperthyroid) } \\
\mathrm{n}=2, \mathbf{N}(\%)\end{array}$ & $\begin{array}{l}\text { Group } 5 \\
\text { (overt } \\
\text { hyperthyroid) } \\
\text { n=1, N (\%) }\end{array}$ \\
\hline Spontaneous labour & $28(56)$ & $6(17.1)$ & $2(16.7)$ & $01(50)$ & 00 \\
\hline Induction of labour & $07(14)$ & $15(42.85)$ & $2(16.67)$ & $01(50)$ & $01(100)$ \\
\hline Caesarian section & $9(17)$ & $8(22.85)$ & $4(33)$ & 00 & 00 \\
\hline
\end{tabular}

Table 4: Foetal outcome.

\begin{tabular}{|c|c|c|c|c|c|}
\hline Foetal outcome & $\begin{array}{l}\text { Group } 1 \\
\text { (euthyroid) } \\
\mathbf{n = 5 0 , N}(\%)\end{array}$ & $\begin{array}{l}\text { Group } 2 \\
\text { (subclinical } \\
\text { hypothyroid) } \\
\mathbf{n}=35, \mathbf{N}(\%)\end{array}$ & $\begin{array}{l}\text { Group } 3 \\
\text { (overt } \\
\text { hypothyroid) } \\
\mathrm{n}=12, \mathrm{n}(\%)\end{array}$ & $\begin{array}{l}\text { Group } 4 \\
\text { (subclinical } \\
\text { hyperthyroid) } \\
n=2, n(\%)\end{array}$ & $\begin{array}{l}\text { Group } 5 \\
\text { (overt } \\
\text { hyperthyroid) } \\
\mathrm{n}=1, \mathrm{~N}(\%)\end{array}$ \\
\hline Pre term birth & $8(16)$ & $6(17.14)$ & $4(33.4)$ & 00 & 00 \\
\hline Low birth weight & $9(18)$ & $14(40)$ & $7(58.33)$ & $01(50)$ & 00 \\
\hline IUGR & $2(4)$ & $6(17.14)$ & $5(41.7)$ & 00 & 00 \\
\hline IUD & $2(4)$ & $4(11.4)$ & $2(16.7)$ & 00 & 00 \\
\hline
\end{tabular}

Table 5: ICU admission.

\begin{tabular}{|c|c|c|c|c|c|}
\hline $\begin{array}{l}\text { Foetal } \\
\text { outcome }\end{array}$ & $\begin{array}{l}\text { Group } 1 \\
\text { (euthyroid) } \\
\text { n=50, N (\%) }\end{array}$ & $\begin{array}{l}\text { Group } 2 \\
\text { (subclinical } \\
\text { hypothyroid) } \\
\text { n=35, N (\%) }\end{array}$ & $\begin{array}{l}\text { Group } 3 \\
\text { (overt } \\
\text { hypothyroid) } \\
\mathrm{n}=12, \mathrm{~N}(\%)\end{array}$ & $\begin{array}{l}\text { Group4 } \\
\text { (subclinical } \\
\text { hyperthyroid) } \\
\mathrm{n}=2, \mathrm{~N}(\%)\end{array}$ & $\begin{array}{l}\text { Group } 5 \\
\text { (overt } \\
\text { hyperthyroid) } \\
\mathrm{n}=1, \mathrm{~N}(\%)\end{array}$ \\
\hline ICU admission & $5(10)$ & $6(17.1)$ & $5(41.7)$ & 00 & 00 \\
\hline
\end{tabular}

\section{DISCUSSION}

This study at SAIMS and PGI, Indore (M.P.) was a prospective, observational, case-control study. In this study, the fetal outcome of 50 hypothyroid pregnant patients (subclinical hypothyroidism, overt hypothyroidism, Subclinical hyperthyroidism and overt hyperthyroidism) was studied in comparison to the 50 euthyroid pregnant patients who served as matched controls. All the patients included in the study were provided regular antenatal checkup. Routine investigations including ultra-sonography for fetal wellbeing and growth parameters were done. Iron and calcium supplementation was given to all patients. All hypothyroid patients were given optimum dose of thyroxine so as to ensure euthyroid state and subsequent good fetal outcome. ${ }^{23}$ Thyroid dysfunction is associated with adverse maternal and fetal outcomes in pregnancy. Thyroid hormone secretion physiological increases during pregnancy to meet the increase requirement of pregnant mother and foetus.

Women with marginally low thyroid function might not be able to meet this increase demand, leading to adverse consequences. Women on adequate replacement of thyroxine have good obstetrics outcome. ${ }^{24}$ In the study of Tan et al no statistically differences in adequately treated thyroid patient and euthyroid patient. ${ }^{25}$ Another study Albovich et al had shown same result that adequate treatment of thyroid disordered patient make it possible for pregnancy to be carried till term without added risk of complications. ${ }^{9}$ 


\section{Maternal outcome}

Women suffering from overt and subclinical hypothyroidism and hyperthyroidism are mainly nulliparous than Euthyroid patient, because most of the patients conceive after infertility treatment and also due to current trend of older women become pregnant. So, in present study, it is noted that overt hypothyroid and overt hyperthyroid women had higher maternal age as compared to women in the other groups. ${ }^{26,27}$ Median age 28.5 years comparable to Nidhi et al which was 26.7 year. In the study 50 thyroid disorder patient were studied among them vaginal delivery by spontaneous labour in different groups. $56 \%$ of euthyroid, $17.1 \%$ of subclinical hypothyroid, $16.7 \%$ of overt hypothyroid, $50 \%$ of subclinical hyperthyroid and by induction of labour. $14 \%$ of euthyroid, $42.86 \%$ of subclinical hypothyroid, $16.67 \%$ of overt hypothyroid, $50 \%$ of subclinical hyperthyroid, $100 \%$ of overt hyperthyroidism cases. The rate of caesarean section was significantly higher in patients with overt hypothyroidism (33 vs. $17 \% \mathrm{P}=0.0031$ ) as compared to the euthyroid controls. No significant increase was seen in the subclinical hypothyroid and hyperthyroid groups. So rate of vaginal delivery more $76 \%$ as compared to c-section $24 \%$. This was comparable to Nidhi et al who had more vaginal delivery but in Dhara et al rate of c-section is more. ${ }^{28}$

\section{Perinatal outcome}

Shows adverse fetal outcomes preterm birth in $33.3 \%$ of overt hypothyroid, $17.14 \%$ subclinical hypothyroid as compared to $16 \%$ of the euthyroid women. Preterm birth was found to be statistically significant $(\mathrm{P}=0.02)$. Similar study by Negro et al found preterm delivery in altered thyroid profile patient as compared to euthyroid patient.

In the study mean birth weight in the group 1 was $2.61 \pm 0.45$, in group 2 was $2.58 \pm 0.7$, in group 3 was $2.2 \pm 0.8$, in group 4 was $2.9 \pm 0.3$, and in group 5 was $2.8 \pm 0.15$. Mean birth weight in group 3 was significantly lower than that in Group $1(\mathrm{P}=0.0002)$. Mean birth weights in group 2, 4, and 5 were not statistically significant. In $58.33 \%$ of overt hypothyroidism and $40 \%$ of subclinical hypothyroid patient's baby have low birth weight (50vs. $26 \%$ ) as compared to the euthyroid women's baby (18\%), found to be highly significant. In the study by Blazer et al birth weight was statistically smaller than control group. ${ }^{29}$

Intrauterine growth retardation in $41.7 \%$ of overt hypothyroidism $17.14 \%$ of subclinical hypothyroid patient's baby is as compared to $4 \%$ of the euthyroid women, found to be highly significant $(\mathrm{P}=0.02)$.

In present study intrauterine death among overt hypothyroidism (16.6 vs. $4 \%, \mathrm{P}=0.024)$ as compared to the euthyroid women, found to be highly significant. Which was same as found in study of Allen et al, but it was not significant in subclinical hypothyroidism and hyperthyroidism as compared with euthyroid patient. $16.7 \%$ hypothyroid patient had history of still birth which was equivalent to study of Buckshee et al.

Allan et al. showed that TSH levels greater than 6 $\mathrm{mU} /$ liter were significantly associated with a higher frequency of stillbirth. ${ }^{30}$ Benhadi et al found that high maternal TSH levels were associated with an increased risk of pregnancy loss. Because TSH is inversely related to hCG levels, women with low hCG levels are at a greater risk of child loss. ${ }^{31}$

Apgar score $<7$ at 1 min was seen in $37.5 \%$ of overt hypothyroid as compared to $5.4 \%$ of euthyroid neonates and was found to be statistically significant $(\mathrm{P}=0.0088)$. I.C.U. admission in low Apgar score $41.7 \%$ of overt hypothyroidism, $17.14 \%$ of subclinical hypothyroid patient's baby, as compared to the $4 \%$ of euthyroid women baby. It found to be highly significant $(\mathrm{P}=0.064)$. In addition, maternal subclinical hypothyroidism increased the risk of fetal distress, which is in agreement with the study of Goel et al. ${ }^{32}$ who reported a higher incidence of fetal distress in pregnancies complicated by maternal hypothyroidism (subclinical hypothyroidism, euthyroid on replacement therapy, and overt hypothyroidism); it has been suggested that hypothyroidism may exert irreversible effects on the fetus and placenta in early pregnancy, which impair their subsequent ability to tolerate stress, thereby increasing the incidence of fetal distress in labor. ${ }^{33}$ Fetal distress may impair infant developmental of the nervous system. ${ }^{34}$ Although hyperthyroidism in pregnancy is uncommon, effects on both the mother and child are critical. However, in present study, no significant finding was seen as the sample size was small and the disease is comparatively infrequent. ${ }^{35}$ The present study also shows that depression was associated with $25 \%$ hypothyroid mothers including both pre and post delivery period. Especially those patients who underwent LSCS as compared to control group had slow recovery and increased drowsiness and loss appetite and constipation. Therefore, the hypothyroidism seems to be the contributing factor for postpartum depression. Thyroxine dose increment was seen in $56 \%$ cases. The mean daily dose of thyroxine was found to be $120 \mathrm{mcg} /$ day in pregnancy.Thyroxine replacement was required in one baby born to the hypothyroid mother. There were main limitations in present study that TPO antibody levels were not examined in all the patients.

\section{CONCLUSION}

It is best to screen women early in the pregnancy for thyroid dysfunction because thyroid diseases satisfy most of the criteria for a disease to warrant population screening. Screening for thyroid dysfunction in a woman who is pregnant or wants to be pregnant is important because thyroid hormone status is directly related to fetal brain development. 


\section{ACKNOWLEDGMENTS}

Authors would like to thank Dr. Suneel Singh Sengar for the support during study.

Funding: No funding sources

Conflict of interest: None declared

Ethical approval: The study was approved by the Institutional Ethics Committee

\section{REFERENCES}

1. Mestman. J. H. (2003). Do abnormal thyroid function tests in pregnancy always mean thyroid abnormality? Program of the American Association of Clinical Endocrinologists $12^{\text {th }}$ Annual Meeting and Clinical Congress. 2003; San Diego, California.

2. Szpunar WE, Stoffer SS, DiGiulio W. Clinical evaluation of a thyroxine binding globulin assay in calculating a free thyroxine index in normal, thyroid disease, and sick euthyroid patients. J Nucl Med. 1987;28(8):1341-3

3. Brent GA. Maternal Thyroid function: Interpretation of thyroid function tests in pregnancy Clinic Obstet Gynecol. 1997;1( 40):3-15

4. Lazarus JH. Epidemiology and prevention of thyroid disease in pregnancy. Thyroid.2002;12(10):861-5.

5. Negro R, Formoso G, Mangieri T, Pezzarossa A, Dazzi D, Hassan H. Levothyroxine treatment in euthyroid pregnant women with autoimmune thyroid disease: effects on obstetrical complications. J Clinic Endocrinol Metabol. 2006 ;91(7):2587-91.

6. Girling JC. Thyroid disorders in pregnancy. Current Obstet Gynaecol.2006;16:47-53.

7. Glinoer D. The systematic screening and management of hypothyroidism and hyperthyroidism during pregnancy. Trends Endocrinol Metabol. 1998;9(10):403-11.

8. Khandakar MA, Ali MS, Kahtun M. Thyroid status of normal pregnant women in Dhaka City. Mymensingh Med J: MMJ. 2002;11(1):1-5.

9. Abalovich M, Gutierrez S, Alcaraz G, Maccallini G, Garcia A, Levalle O. Overt and subclinical hypothyroidism complicating pregnancy. Thyroid. $2002 ; 12(1): 63-8$

10. Maggie A, Abbey F. Physiology And Pathophysiology text book/Thyroid hormones and disorders

11. Casey BM, Dashe JS, Wells CE, McIntire DD, Byrd W, Leveno KJ, et al. Subclinical hypothyroidism and pregnancy outcomes. Obstet Gynecol. 2005;105(2):239-45.

12. Woeber KA. Subclinical thyroid dysfunction. Arch Int Med. 1997;157(10):1065-8.

13. Jayme JJ, Ladenson PW. Subclinical thyroid dysfunction in the elderly. Trends Endocrinol Metabol. 1994;5(2):79-86.

14. Hamburger JI. Diagnosis and management of Graves' disease in pregnancy. Thyroid. 1992;2(3):219-24.
15. Davis LE, Lucas MJ, Hankins GD, Roark ML, Cunningham FG. Thyrotoxicosis complicating pregnancy. Am J Obstet Gynecol. 1989;160(1):6370 .

16. Goodwin TM, Montoro MA, Mestman JH, Pekary AE, Hershman JM. The role of chorionic gonadotropin in transient hyperthyroidism of hyperemesis gravidarum. J Clinical Endocrinol Metabol. 1992;75(5):1333-7.

17. Nelson-Piercy C, Girling J. Essay questions. 4.3. Hyperthyroidism. In: Nelson-Piercy C, Girling J, eds. Obstetric Med: a problem-based approach London: Springer, 2007

18. Kriplani A, Buckshee K, Bhargava VL, Takkar D, Ammini AC. Maternal and perinatal outcome in thyrotoxicosis complicating pregnancy. European $\mathrm{J}$ Obstet Gynecol Reproduct Biol. 1994;54(3):159-63.

19. Sheffield JS, Cunningham FG. Thyrotoxicosis and heart failure that complicate pregnancy. Am J Obstet Gynecol. 2004;190(1):211-7.

20. Mulder JE. Thyroid disease in women. Med Clinic North Am. 1998;82(1):103-25.

21. American Thyroid Association (ATA), (2002 a). "Hypothyroidism," Zpatient Fact Sheet.

22. Chauhan N, Nautiyal R. To study the profile of thyroid function in pregnancy and its correlation with the maternal and fetal outcome. Int J Biol Med Res. 2014;5(4):4565-8.

23. Zimmermann MB, Burgi H, Hurrell RF. Iron deficiency predicts poor maternal thyroid status during pregnancy. J Clinic Endocrinol Metabol. 2007;92(9):3436-40.

24. Negro R, Schwartz A, Gismondi R, Tinelli A, Mangieri T, Stagnaro-Green A. Thyroid antibody positivity during pregnancy. J Clin Endocrinol Metab. 2011;96(1):E920-4.

25. Tan TO, Cheng YW, Caughey AB. Are women who are treated for hypothyroidism at risk for pregnancy complications? American J Obstetrics Gynecol. 2006;194(5):e1-3.

26. Altomare M, La Vignera S, Asero P, Recupero D, Condorelli RA, Scollo P, et al. High prevalence of thyroid dysfunction in pregnant women. J Endocrinol Invest. 2013;36(6):407-11

27. Unnikrishnan AG, Kalra S, Sahay RK, Bantwal G, John M, Tewari N. Prevalence of hypothyroidism in adults: An epidemiological study in eight cities of India. Indian J Endocrinol Metabol. 2013;17(4):647.

28. Dhara S, Bhati I, Bora S, Meena S. Study of thyroid dysfunction in pregnancy. Int J Curr Microbiol App Sci. 2015;4(9):91-7.

29. Blazer S, Moreh-Waterman Y, Miller-Lotan R, Tamir A, Hochberg ZE. Maternal hypothyroidism may affect fetal growth and neonatal thyroid function. Obstet Gynecol. 2003;102(2):232-41.

30. Allan WC, Haddow JE, Palomaki GE, Williams JR, Mitchell ML, Hermos RJ et al. Maternal thyroid deficiency and pregnancy complications: implications for population screening. J Med Screen. 2000;7(3):127-30. 
31. Benhadi N, Wiersinga WM, Reitsma JB, et al. Higher maternal TSH levels in pregnancy are associated with increased risk for miscarriage, fetal or neonatal death. Eur J Endocrinol. 2009;160(6):985-91.

32. Goel P, Radotra A, Devi K, Malhotra S, Aggarwal A, Huria A. Maternal and perinatal outcome in pregnancy with hypothyroidism. Indian J Med Sci. 2005;59(3).

33. Sahu MT, Das V, Mittal S, Agarwal A, Sahu M. Overt and subclinical thyroid dysfunction among Indian pregnant women and its effect on maternal and fetal outcome. Arch Gynecol Obstet. 2010;281(2):215.

34. Casey BM, Dashe JS, Wells CE, McIntire DD, Leveno KJ, Cunningham FG. Subclinical hyperthyroidism and pregnancy outcomes. Obstet Gynecol. 2006;107(2):337-41.

35. Haddow JE, Palomaki GE, Allan WC, Williams JR, Knight GJ, Gagnon $J$ et al. Maternal thyroid deficiency during pregnancy and subsequent neuropsychological development of the child. New Eng J Med. 1999;341(8):549-55.

Cite this article as: Singh V, Natu N, Gupta AS. Comparison of maternal and perinatal outcome in pregnancy with altered thyroid profile and euthyroid patients: a prospective, observational and case control study in a tertiary care centre. Int J Reprod Contracept Obstet Gynecol 2019;8:1594-600. 